\title{
THE PARADOX BETWEEN POLITICAL ISLAM AND ISLAMIC POLITICAL PARTIES: The Case of West Sumatera Province
}

\section{Adri Wanto}

S. Rajaratnam School of International Studies (RSIS), Nanyang Technological University (NTU), Singapore

\section{Abstract}

The aim of this paper is to explain the apparent paradox between political Islam and Islamic political parties in Indonesia. On one hand, the support for Islamic political parties is in decline, while, on the other religious intolerance and the implementation of local regulations based on the shariab laws have increased in many provinces. This paper argues that political Islam and Islamic political parties are not synonymous. Moreover, the aim of achieving an ideal society according to an Islamist's vision and their religious interpretations does not only by adopt a top-down strategic model through participation in formal politics but also by using bottom-up strategic model by focusing on the societal level. By adopting gradualist approaches, hardliner Islamist ideas disseminate peacefully in Indonesia today. This study will focus on West-Sumatra as a case study, considering West Sumatra is one of the most widely province issued the shari'ah laws in Indonesia. This article will shed light on local and often underestimated dynamics.

[Artikel ini menjelaskan paradoks antara Islam politik dan partai politik Islam di Indonesia. Jika pada satu sisi, dukungan terhadap partai politik Islam menurun, namun pada sisi berbeda tingkat intoleransi dan angka peraturan daerah berbasiskan syariah meningkat. Karena itu, artikel ini berargumen bahwa Islam politik dan partai politik Islam tidak selalu sejalan. Selain itu, cita-cita untuk mewujudkan masyarakat yang Islami tidak melulu 
harus diwnjudkan dari atas-ke-bawah melaluipartisipasipolitik, namun juga dari bawah-ke-atas, yakni menitikberatkan pada level masyarakat. Dengan strategi gradual-perlahan-lahan-, gagasan fundamentalis Islam tanpa sadar telah menginfiltrasi. Artikel ini menjelaskan Sumatra Barat sebagai studi kasus persoalan di atas. Piliban Sumatra Barat berdasarkan pada realitas bahwa di propinsi inilah, perda shari'ah paling banyak diberlakukan. Artikel ini akan berkontribusi pada diskusi mengenai politik lokal dan dinamikanya.]

Keywords: Political Islam, Minangkabau, shari'ah laws

\section{A. Introduction}

Since the fall of the Suharto regime in 1998 and the implementation of democracy through free and fair elections, aspirations among Islamic religious elites for having better access to the state power had been raised. Consequently, some have chosen to establish Islamic political parties to participate in elections. Among the 48 parties eligible to take part in the 1999 election, 21 were Islamic parties. ${ }^{1}$ The Islamic religious elites believed that through participation in formal politics, they could achieve their vision of an ideal society, according to their interpretation on Islamic teaching, by using a top-down strategic model.

Following the collapse of the Suharto regime, the emergence of political Islam was one of the crucial political issues among many others, such as, pushing for democracy and civilian's rights, military reform and regional autonomy, as discussed by experts. ${ }^{2}$ They were concerned that

${ }^{1}$ Greg Barton, "the Prospects for Islam", in G. Lloyd and S. Smith (eds.), Indonesia Today: Challenges of History (Singapore: Singapore Institute of Southeast Asian Studies, 2001), p. 246.

${ }^{2}$ Dwight King, Half-hearted Reform: Electoral Institutions and the Struggle for Democracy in Indonesia (Westport, Conn: Praeger 2003); Steele Andrew, "the Decline of Political Islam in Indonesia 2006, Asia Time, March 28, 2006 [http://www.atimes.com/atimes/ Southeast_Asia/HC28Ae03.html]; Greg Fealy, Local Power and Politics in Indonesia: Decentralisation \& Democratisation (Singapore: Institute of Southeast Asian Studies, 2003); Anies Rasyid Baswedan, "Political Islam in Indonesia, Present and Future Trajectory", Asian Survey, 44, 5, 2004; William R. Liddle and Saiful Mujani, "Leadership, Party, and Religion: Explaining Voting Behaviour in Indonesia," Comparative Politics Studies, 40, 7, 2009; Bernhard Platzdasch, "Down but Not Out: Islamic Political Parties did not do well, but Islamic Politics going Mainstream,” Inside Indonesia, 97, 2009 [http://www. 
Indonesia's fledgling democracy would be hijacked by Islamist ${ }^{3}$ group(s) and would become an Islamic state. These concerns are understandable, considering that Indonesia is a Muslim majority country and large numbers of Islamic parties had been established post reformasi (reform). However, by observing popular support for the Islamic parties over the past ten years, many scholars concluded that the majority of Muslim voters did not to regard Islam as critical factor to their electoral decisions. ${ }^{4}$

The aforementioned scholars' argument can be proven empirically base on the result of the elections from 1999 to 2009. Election outcomes indicate that popular support for Islamic parties has declined despite the fact that majority of voters, more than $88 \%$, are Muslims. This had resulted in definitive pronouncement by scholars arguing that Indonesia's democracy would not be hampered by the growth of political Islam since the popular support for Islamic parties had declined collectively. ${ }^{5} \mathrm{~A}$ similar argument was also pounded by Liddle and Mujani who argued that the declining of support for religious parties indicates popular disapproval of the enforcement of shari'ab or other forms of Islamism in Indonesian political life. ${ }^{6}$ They argued that the decline of popular support for Islamic parties is synonymous of the decline of political Islam.

The hypothesis that Islamic party is synonymous with political

insideindonesia.org/edition-97-jul-sep-2009/down-but-not-out-05071210].

${ }^{3}$ Term 'islamist' is referring to Fuller's definition on Political Islam or Islamism. He argued that "Islamist is one who believes that Islam as body of faith has something important to say about how politics and society should be ordered in the contemporary Muslim World and who seeks to implement this idea in some fashion." See Graham E. Fuller, The Future of Political Islam (New York: Palgrave Macmillan, 2003).

${ }^{4}$ Dwight King, "Half-hearted reform"; Steele Andrew, "the Decline of Political Islam"; R. Liddle, William and Saiful Mujani, "Leadership, Party, and Religion”; Bernhard Platzdasch, Down but Not Out"; Andreas Ufen, "From Aliran to dealignment: Political Parties in post-Soeharto Indonesia", Southeast Asia Research, 16, 1, 2008; Greg Fealy, "Indonesia's Islamic Parties in Decline," Inside Story, 2009 [http://inside.org.au/ indonesia $\% \mathrm{E} 2 \% 80 \% 99$ s-islamic-parties-in-decline/]; Sunny Tanuwijaya, "Political Islam and Islamic Parties in Indonesia: Critical Assessing the Evidence of Islam's Political Decline", Contemporary Southeast Asia, 32, 1, 2010; Kikue Hamayotsu, "The End of Political Islam? A Comparative Analysis of Religious Parties in the Muslim Democracy Indonesia", Journal of Current Southeast Asia Affairs, 30, 3, 2011.

${ }^{5}$ Hamayotsu, Kikue “The End of Political Islam?”, pp. 133-159.

${ }^{6}$ R. Liddle, William and Saiful Mujani, "Leadership, Party, and Religion"; pp. 832-857. 
Islam has to be tested. Is Hamayotsu's contention that the decline of the Islamic political parties, particularly in the post reform era, signals the decline of political Islam? ${ }^{7}$ If that is the rationale, then what explains the increased implementation of shariah laws at the regional level, almost all over the Indonesian archipelago? Is the support for Islamic parties bound to fail because of their exclusive and puritanical ideology and illiberal character? ${ }^{8}$ Can it be understood that the decline of Islamic political parties mean that Muslims in Indonesia are becoming more liberal, more respectful of human rights and pluralism? If so, how do we explain the rise of religious intolerance over the past ten years? How do we explain this paradox?

There is a research chasm needs to be filled to understand the link between political Islam and the Islamic political parties. To fill the gap, we must disentangle both variables. An accepted definition in the scholarly literature refers to political Islam as a body of faith that believes that politics, society and the public sphere should be ordered according to Islamic religious ideals and principle. ${ }^{9}$ Islamic political parties are one aspect of a strategy and effort to achieve an ideal society according to the Islamic principles. The concept of political Islam presupposes idealistic philosophies, romantic, and abstract Islamic ideals. Meanwhile, Islamic political parties constitute a means of bridging religious ideas and reality. In other words, Political Islam is an 'idea' while an Islamic political party is a 'strategy' to enable an idea to become reality. By explaining the differences between these concepts, be able to cut the Gordian knot created by the statement that political Islam's decline corresponds with the decline of Islamic political parties.

However, we need to emphasize that achieving an ideal society according to Islamist interpretations, requires not only through participating in formal politics, but also the use of a bottom-up strategic model by focusing primarily at the societal level. Indonesian Islamists believe that their vision of an ideal society and politics could materialize effectively by with the society as a focal point. For example, Irfianda Abidin Datuk Penghulu, the Chairman of Islamic Law Enforcement

\footnotetext{
${ }^{7}$ Kikue Hamayotsu, "The End of Political Islam?".

8 See Graham E. Fuller, The Future of Political Islam.

9 Ibid, p. ix.
} 
Committee (Komite Penerapan Syariat Islam, KPSI) of West Sumatra, stated:

"Although shari'ab regulations have not been implemented thoroughly in West Sumatra, we can see the increasingly growing awareness to enforce Islamic laws and practices in the society level. Therefore, besides struggling for the implementation of shariah regulations, we have to focus on the society as a focal point". ${ }^{10}$

Therefore, instead of participating in formal politics, some religious elites decided to establish Islamic movements. In other words, in manifestations of political Islam are not only evident in Islamic political parties; but also in Islamic movements with society as a focal point. Islamic Mass Organizations (Organisasi Massa, Ormas) are considered to be one group of key actors in such a movement. The Komite Penerapan Syariat Islam (KPSI), Gerakan Muslim Minangkabau (GMM), and Front Masyarakat Pembela Islam (FMPI) are the most active mass organizations in promoting shari'ab laws in West Sumatra. Beside the local Islamic mass organizations, the Java-based Islamic groups, such as, Hizbut Tahrir Indonesia (HTI), Majelis Mujahidin Indonesia (MMI), and Islamic Defender Front (FPI), also very active in promoting the formalization of shari'ab laws. Since the end of Suharto era, these organizations have established their local branches in West Sumatra.

This article attempts to address the gap in the literature that fails to address why political Islam endures and continues to grow despite declining support for political parties by analysing the link between political Islam and Islamic political parties in the wider context. The paper argues that a decline of support for Islamic parties does not necessarily mean that political Islam is on decline. Also, those who support political Islam agendas may not automatically join or support the Islamic parties since Islamist hardline groups, generally, do not support democratic elections. Therefore, the increase or decrease of political Islam in Indonesia may not be a reflection of Muslim's people's support for the Islamic political parties.

In answering the questions and explaining the aforementioned paradox, the discussion will focus on two levels; the provincial level

${ }^{10}$ Interview with Abidin Datuk Penghulu, the Chairman of Islamic Law Enforcement Committee (KPSI) of West Sumatra conducted on August 2012. 
and the regional level. For the provincial level, we have chosen the West Sumatera province as a case study, considering West Sumatra is one of the most widely province issued the shari'ah laws in Indonesia. Meanwhile, for the regional level, we have chosen Tanah Datar and Padang Pariaman region. Historically, Tanah Datar was known as Luhak nan Tuo, the 'centre' of the Minangkabau ${ }^{11}$ ethnic group. Meanwhile, Padang Pariaman was known as a propagation basis of Islam in Minangkabau.

The findings in this article are primarily based on fieldwork conducted from 2011 to 2012. To obtain information related to this topic, we conducted in-depth interviews with cadres and party elites at the provincial and regional levels; whit number of Islamic organizations; and with local leaders and scholars in the West Sumatera province. Previous study on political Islam in Indonesia, focused on the relationship between political Islam and electoral and constitutional changes, but is largely neglected in the studies of the change of Indonesian Muslim's behaviour toward politics. Therefore, the scope of this study focuses on Political Islam and Indonesian Muslim behaviour, especially Minangkabau people toward politics.

\section{B. Political Islam in West Sumatra Post Reformasi}

The support for Islamic political parties over the past ten years has declined in Indonesia. In the 1999 election, Islamic parties obtained 33.73 percent of the vote to secure 163 seats in parliament (Dewan Perwakilan Rakyat, DPR). However, the vote diminished to 25.83 per cent in 2009; although there was a momentary increase to 35.12 per cent to secure 219 legislative seats in 2004 due to the dramatic expansion of Prosperous and Justice Parties (Partai keadilan Sejahtera, PKS) (see Table 1).

Yet, the decline of Islamic parties post reform era does not mean that Indonesian's Muslims no longer support political Islam. Although the support for Islamic political parties has declined, a large number of local regulations (Peraturan Daerah, Perda) based on shariah law have

11 'Minangkabau' refers to an ethnic group in central Sumatra. The term can also refer to the territory occupied by this ethnic group. Therefore, the word 'Minangkabau' is often used interchangeably. Since joining the Republic of Indonesia, Minangkabau territorial areas were centralised into a province under Indonesian rules called West Sumatra. Therefore, the majority of West Sumatra's population is dominated by the Minangkabau ethnic group. 
The Paradox between Political Islam and Islamic Political Parties

\section{Table 1:}

Islamic Parties in the House of Representatives (DPR), 1999-2009

\begin{tabular}{|l|l|l|l|l|l|l|}
\hline \multirow{2}{*}{ Parties } & \multicolumn{2}{c|}{1999} & \multicolumn{2}{c|}{2004} & \multicolumn{2}{c|}{2009} \\
\cline { 2 - 7 } & Votes (\%) & Seats & Votes (\%) & Seats & Votes (\%) & Seats \\
\hline $\begin{array}{l}\text { National Mandate } \\
\text { Party (PAN) }\end{array}$ & 7.12 & 34 & 6.44 & 53 & 6.01 & 43 \\
\hline $\begin{array}{l}\text { Crescent Star Party } \\
\text { (PBB) }\end{array}$ & 1.94 & 13 & 2.62 & 11 & 1.8 & 0 \\
\hline $\begin{array}{l}\text { National Awakening } \\
\text { Party (PKB) }\end{array}$ & 12.61 & 51 & 10.57 & 52 & 4.94 & 27 \\
\hline $\begin{array}{l}\text { Prosperous Justice } \\
\text { Party (PKS) }\end{array}$ & 1.36 & 7 & 7.34 & 45 & 7.8 & 57 \\
\hline $\begin{array}{l}\text { United Development } \\
\text { Party (PPP) }\end{array}$ & 10.7 & 58 & 8.15 & 58 & 5.3 & 39 \\
\hline Total & $\mathbf{3 3 . 7 3}$ & $\mathbf{1 6 3}$ & $\mathbf{3 5 . 1 2}$ & $\mathbf{2 1 9}$ & $\mathbf{2 5 . 8 3}$ & $\mathbf{1 6 6}$ \\
\hline
\end{tabular}

Source: Indonesia Memilih, the General Election Commission (KPU)

been implemented at the provincial and district level all over Indonesia. As many as 78 shariah laws had been issued in 52 regencies in the country, ${ }^{12} 26$ among them, implemented in West Sumatra province (See table 2 below).

Interestingly, the implementations of shari'ab laws in West Sumatra were generally established by the secular parties. The Golkar, a secular party, often proposes the implementation of shariab laws in the province. The argument made is that such phenomenon illustrates that political parties no longer have a clear ideology and have turned into very pragmatic organizations in order to gain political power. ${ }^{13}$ Scholars like Anna Seleny have argued that pragmatism is typically associated with modern democracy. ${ }^{14}$ Pragmatism is a reaction against idealistic philosophies, romantic, and abstract, countering instead that the truth of

12 "Syariah Bylaws: 'Time Bomb”, Jakarta Post, April, 20, 2012.

13 Anies Rasyid Baswedan, "Political Islam in Indonesia", pp. 669-90.

${ }^{14}$ Anna Seleny, " "Tradition, Modernity and Democracy: the Many Promises of Islam”, Prospective on politics, Vol. 4, No. 3, September, 2006, pp. 481-94. 


\section{Table 2:}

Perda shariah implemented in West-Sumatera since reform Era

\begin{tabular}{|c|c|}
\hline Year & tion \\
\hline 2001 & $\begin{array}{l}\text { Provincial level: Provincial regulation number } 11 / 2001 \text { on the Control } \\
\text { of, and Action of, Social Illnesses. } \\
\text { Tanah Datar Regent, Mayor Instruction letter Number } 451.4 / 556 / \\
\text { Kesra- } 2001 \text { on the Imposition of the obligation to wear Islamic Outfit } \\
\text { for civil servants. } \\
\text { Solok Regent, Local regulation Number 10/2001 On Quranic Literacy } \\
\text { for Pupils, Students, Brides and Grooms-to-be. }\end{array}$ \\
\hline 2002 & $\begin{array}{l}\text { Solok Regent, Local Regulation Number 6/2002 on the Islamic } \\
\text { outfit. }\end{array}$ \\
\hline 2003 & $\begin{array}{l}\text { Padang Regent, Local Regulation Number } 6 / 2003 \text { on the } \\
\text { comprehensive Koran Literacy for Regular and Islamic Elementary } \\
\text { School Students. } \\
\text { Padang Regent, Local Regulation Number } 3 / 2003 \text { on the } \\
\text { comprehensive Koran Literacy for Muslims. } \\
\text { Solok Regent, Local Regulation Number } 13 / 2003 \text { on the } \\
\text { Management of Profession Alms and Any Kind of Charitable } \\
\text { Contribution. } \\
\text { Bukittinggi Regent, Local Regulation Number } 20 / 2003 \text { on the } \\
\text { amendment of the local regulation Number } 09 / 2000 \text { on the Control } \\
\text { of, and Action of, Social Illnesses. } \\
\text { Sawah Lunto Regent, Local Regulation Number } 01 / 2003 \text { On Quranic } \\
\text { Literacy for Pupils, Students, Brides and Grooms-to-be. } \\
\text { Sawah Lunto Regent, Local Regulation Number } 02 / 2003 \text { on the } \\
\text { Islamic outfit. } \\
\text { Pasaman Regent, Local Regulation Number } 22 / 2003 \text { on the } \\
\text { obligation to wear the Islamic outfit for Students and Employees. } \\
\text { Pasaman Regent, Local Regulation Number } 21 / 2003 \text { on the } \\
\text { comprehensive Quranic Literacy. } \\
\text { Pesisir Selatan Regent, Local Regulation Number } 31 / 2003 \text { on the } \\
\text { Management of Profession Alms and Any Kind of Charitable } \\
\text { Contribution. } \\
\text { Lima Puluh Kota Regent, Local Regulation Number } 6 / 2003 \text { on } \\
\text { Quranic Literacy for Pupils, Students, Brides and Grooms-to-be }\end{array}$ \\
\hline 200 & $\begin{array}{l}\text { Padang Pariaman Regent, Local Regulation Number 02/2004 on the } \\
\text { Prevention and Eradication and Suppression of Social Illnesses. } \\
\text { Padang Panjang Regent, Local Regulation Number 03/2004 on the } \\
\text { Prevention and Eradication and Suppression of Social Illnesses. } \\
\text { Bukittinggi Regent, Local Regulation Number } 29 / 2004 \text { on the } \\
\text { Management of Profession Alms and Any Kind of Charitable } \\
\text { Contribution. } \\
\text { Pesisir Selatan Regent, Local Regulation Number } 08 / 2004 \text { on } \\
\text { Quranic Literacy for Pupils, Students, Brides and Grooms-to-be }\end{array}$ \\
\hline
\end{tabular}




\begin{tabular}{|c|c|}
\hline 2005 & $\begin{array}{l}\text { Provincial level: Provincial Regulation number } 07 / 2005 \\
\text { comprehensive Quranic Literacy. } \\
\text { Provincial level: Governor circulation letter number } 260 / 421 / \mathrm{X} / \mathrm{PPr}- \\
05 \text { on the obligation to wear the Islamic outfit for civil servants. } \\
\text { Pesisir Selatan Regent, Local Regulation Number } 04 / 2005 \text { on Islamic } \\
\text { outfit. } \\
\text { Agam Regent, Local Regulation Number } 06 / 2005 \text { on the Islamic } \\
\text { outfit. } \\
\text { Padang Regent, Mayor Instruction Number } 451.422 / \text { Binsos-III/2005 } \\
\text { on } 07 \text { March } 2005 \text { on the obligation to wear a Headscarf and the } \\
\text { Islamic Outfit (for Muslims) and Suggestion (for Non-Muslims). } \\
\text { Padang Regent, Mayor Instruction on } 7 \text { March } 2005 \text { on obligation to } \\
\text { wear the Islamic outfit for Muslim Women }\end{array}$ \\
\hline 200 & $\begin{array}{l}\text { Jumber } 192006 \text { on the } \\
\text { of Social Illnesses. }\end{array}$ \\
\hline 2008 & $\begin{array}{l}\text { dang Panjang Regent, Local Regulation Number } 07 / 2008 \text { on } \\
\text { e Management of Profession Alms and Any Kind of Charitable } \\
\text { ntribution }\end{array}$ \\
\hline
\end{tabular}

Source: Law and Human Right Bureau of West Sumatera Province, Daftar Inventarisasi Rancangan dan Produk. Hukum Daerah Kabupatern/Kota Se-Sumatera Barat 2001-2008.

idea arises from observing its consequences. ${ }^{15}$ Along with the democratic process, political pragmatism is a common practice among political parties in Indonesia. This creates a paradox. The secular parties tend to push vigorously for the implementation of shariahlaws as evident in the West Sumatera province. Correspondingly the Islamic parties have asked for the implementation of secular regulations, as seen in the province of the Riau Islands. A legislative member from the National Awakening Party (PKB), a political party base on the Pancasila and drawing it constituency from Nahdatul Ulama $(\mathrm{NU})$, proposed a bill that the city government to legalise prostitution in Batam Island and collect taxes from the commercial sex workers. ${ }^{16}$

The requirement by the secular parties that shariah laws be implemented reflects the pragmatic attitude of the political parties and their desire to build their political image among Muslims in Indonesia. Secular and nationalist parties, such as Golkar, have become more Islam-friendly and assertive in implementing shari'ah laws to gain more

15 William James, Pragmatism: A New Name for Some Old ways of Thinking (New York: New York Library of America, 1986), pp. 112-113.

16 "Anggota DPRD Batam Usulkan Pajak 10\% dari PSK", Batam Pos, 15 February 2010. 
popular support from the majority of Muslim voters. ${ }^{17}$ However, to understand the context, we need to comprehend not only the dynamic at the constitution and electoral levels but also the nature of political and social change shaping Minangkabau society.

Indonesia's Muslim voters in are becoming more religious, pious, and growing more conservative, however; such traits do not shape their voting behaviour. ${ }^{18}$ The West Sumatra province is not an exception to this trend. The only survival strategy for secular and nationalist parties is become more adaptive to the Islamic agendas combining pragmatism and piety rather than adopting moderate centralist ideologies. This trend exists because the political parties have to keep abreast with social change rather than adopt secularist now deemed idealistic. Therefore, we would contest the argument that "the adoption of a moderate centralist ideology would be key for the political survival of religious parties in emerging democracy". ${ }^{19}$ Such a viewpoint is premature as the political landscape in a region like West Sumatra continues to by dynamic and evolving.

The implementation of shariah law by secular parties in the province of West Sumatra is shaped by two trends, first, the pragmatism of political parties, and second, consistency and idealism of Minangkabau people who remain 'devoted' to their religious. Irrespective of the role of political parties in West Sumatra, the loyalty of elected parliament members to the 'Islamic teaching' is far greater than their loyalty to the political parties that nominate them. For example, Buya Drs. H. Khaidir Bandaro Khatib, parliament member of West Sumatra from National Mandate Party, a political party base on the Pancasila, stated:

"The application of shari'ab laws in West Sumatra is an obligation, as Minangkabau society upholds religious and Minangkabau traditional values. The commitment to religion and tradition is clearly stated in the guiding philosophy of life of Minangkabau people, adaik basandi sarak, sarak, basandi kitabullah. West Sumatra province is left behind compared to Aceh and South Sulawesi, in implementing shariah. Therefore, the local government has to work extra hard to implement the shari'ab laws."20

17 Anies Rasyid Baswedan, "Political Islam in Indonesia", pp. 669-90.

18 Greg Fealy, "Indonesia's Islamic Parties in Decline".

19 Kikue Hamayotsu, "The End of Political Islam?"

${ }^{20}$ The Interview with Buya Drs. H. Khaidir Bandaro Khatib, parliament member of West Sumatra from National Mandate Party was conducted in July 2012. 
Therefore, when they become a member of parliament, they tend to voice their support for the implementation of shariab laws in spite of their political parties background. Therefore, this trend can be summarised as a form of political pragmatism that goes hand in hand with majority Minangkabau beliefs that is shaped by growing religiosity. This trend captures by a survey conducted in 2001 by Research Centre for the Study of Islam and Society (Pusat Kajian Islam dan Masyarakat, PPIM) of Syarif Hidayatullah Islamic State University. The survey shows that religious identity is important to Indonesian when they asses their prospective quality of their government and leaders. The survey shows that 57.8 percent (in 2001) and 67 percent (in 2002) of Indonesians are support the idea that Indonesia political system has to be base on Islamic teaching. ${ }^{21}$

\section{Minangkabau People: Social and Political Changes}

Minangkabau people are well-known for being dynamic, openminded and their egalitarian character. They believe that all people are equal and that no such social stratification exists in the region. Although, historically they have been influenced by Indian culture, there is no 'social class' in Minangkabau. In addition, the Minangkabau people do not recognize the nobility which has a big influence at the supra-village level. ${ }^{22}$

When referring to the political history of Minangkabau, there were two models of traditional governance systems, i.e. bodi chaniago, democracy patterned, and koto piliang, aristocracy patterned. Both governance systems have similarities with the policies of government in ancient Greece. ${ }^{23}$ Datuk Katamanggungan established the Customary law of koto piliang, while the customary law of bodi chaniago was developed by Datuk Parpatih

${ }^{21}$ The PPIM Survey data in 2001 and 2002. The 2001 survey was conducted in sixteen provinces (all provinces in Java. North Sumatra, West Sumatra, South Sumatra, Lampung, Jambi, Riau, South Kalimantan, East Kalimantan, South Sulawesi and West Nusa Tenggara). The 2002 survey was conducted in all provinces except Papua and Maluku.

22 Tsuyoshi Kato, Adat Minangkabau dan Merantau dalam Presfektif Sejarah (Jakarta: Balai Pustaka, 2005), p. 50.

${ }_{23}$ Robert Johnson Bonner, Aspects of Athenian Democracy (California: University of California Press, 1933), pp. 25-86. 
nan Sabatang. ${ }^{24}$

Symbolically, the difference between bodi chaniago and koto piliang is reflected in the construction of the floor of their rumah gadang ${ }^{25}$ (traditional building) hall. The floor of bodi chaniago hall is flat. According to their philosophy "duduk sama rendah, berdiri sama tinggi" (all people are equal). The floor of koto piliang hall has a slightly elevated floor at the end which is where the penghulu pucuak (head of penghulu) is seated. The philosophy of koto piliang is "aie manitiek dari ateh", (water dripping from above). ${ }^{26}$ Although the philosophy of bodi chaniago and koto piliang is different, in practice both traditions were absorbed by the Minangkabau society simultaneously.

In Minangkabau tradition, a leader has a slightly higher position though not significantly enough to create a distance from their people. Both in the tradition of bodi chaniago and koto piliang, leaders cannot adopt a role similar to a king, sultan or emperor. This was reflected in the philosophy of Minangkabau society over the leadership, namely, "didabulukan selangkah, ditinggikan seranting" (precedence a step, elevated a branch). ${ }^{27}$ Traditional leadership in Minangkabau is held by penghulu with the title datuak. A penghulu was elected among members of his tribe and is required to guide and nurture his tribe. In carrying out his task, a penghulu aided by a young penghulu called penghulu panungkeke could act on behalf of the penghulu regarding, both the internal and external affairs of his tribe.

The way Minangkabau people interpret leadership is very unique. Based on Minangkabau adat (custom) rules, a leader such as Mamak or penghulu cannot unilaterally determine a public decision. Every single policy in Minangkabau has to be based on consensus. The process of Musyawarah jo Mufakat has to be based on egalitarianism. Minangkabau

${ }^{24}$ Audrey Kahin, Dari Pemberontakan ke Integrasi: Sumatera Barat dan Politik Indonesia 1926-1998 (Jakarta: Yayasan Obor Indonesia, 2005)

${ }^{25}$ Rumah Gadang (Minangkabau: "big house") is the traditional homes (bahasa: "rumah adat") of the Minangkabau ethnicity. The architecture, construction, internal and external decoration, and the functions of the house reflect the culture and values of the Minangkabau. A rumah gadang serves as a residence, a hall for family meetings, and for ceremonial activities.

${ }^{26}$ Audrey Kahin, Dari Pemberontakan ke Integrasi.

${ }^{27}$ Emeraldy Chatra, Adat Selingkear Desa (Padang: Faculty of social and political science and centre of development and social change studies, University of Andalas, 1999), p. 29. 
people are conditioned to debate and argue. Such characteristics are ingrained in the social dynamic of Minangkabau people. Sandy describes Minangkabau people behaviour:

"Adat teaching is oriented to human morals and feelings. You do not accuse someone directly. You do not criticize directly. You do so with proverbs. It is very rude to point out mistakes directly. There should be no force in decision making. There should be mutual understanding. In Minangkabau democracy there is no room for rivalries. Differences of opinion are regarded as normal — consensus arrives through discussion. About differences of opinion there is a proverb: Crossing wood in the hearth makes the fire glow" 28

The traits shaping Minangkabau values, namely, its open-minded, egalitarian, consensus-base, and democratic culture has shaped the political thinking of the modern Indonesian state's establishment, particularly, since a large number of Indonesian founding fathers and mothers are Minangkabau ethnicity. These elites participated in laying the conceptual foundations for a modern and democratic state for Indonesia. Names like Mohammad Hatta, Sutan Sjahrir, Mohammad Natsir, Tan Malaka, and Rasuna Said are well known as figures that struggled for the Indonesia's Independence and were devoted to ideas of democracy. Their thoughts and the ideas of democracy that they fought for may be adopted from western political thought, but their Minangkabau culture also shaped much of their premises.

At the national level, War of Independence and in the early 1950s it was a 'golden' period for Minangkabau people. The debate about democracy and some other ideologies, such as, communism, was developed among Minangkabau intellectuals, both those who lived outside and in Minangkabau. Although Islam is the only religion of the Minangkabau people, pluralist approaches were adopted my Minangkabau intellectuals when discussing about political ideology reflected in the thinking of figures from West Sumatera and the ideological platform of parties that sprung up in the area. Politically, the Minangkabau were not only affiliated to Islamic parties, but also nationalist, secular, socialist, and communist parties.

28 Peggy Reeves Sanday, Women at the Center: Life in a Modern Matriarchy (Boston: Cornell University Press, 2002), p. 20. 
Initially, the democratic and egalitarian character of the Minangkabau people was, culturally, influenced by certain factors. The character building process of Minangkabau people begins when they are teenagers when they live in surau (a communal house), where they learn to read the Qur'an and learn martial arts. This confirms that the influence of traditional Islam in the formation of democratic values was at the community level.

In Minangkabau, a teenage boy has to live with his peers in the surau. Living in the surau, accustoms boys to live within communal setting under the guidance of village elders. As a result, a boy in Minangkabau gains more freedom compared to a boy from other kinship systems in Indonesia. In addition to building an egalitarian spirit, togetherness and mutual influence among peers, the condition created is also intended to provide greater confidence as a man. This culture has influenced men of Minangkabau to have a democratic attitude. It is the accepted custom for individuals to discuss daily issues and debate with their peers at the social level, for example, with peers instead of their parents. Thus they develop an egalitarian relationship with their mentors rather than with their father. A father is more likely to dominate the relationship, exerting his power over his son. ${ }^{29}$

As teenagers do not stay at home with their parents, ideas and initiatives flourish freely within the surau atmosphere where they can exchange their ideas and join in democratic debates. Therefore, the Minangkabau are also flexible in expressing their opinions. ${ }^{30}$ The practice living in the surau still continues practicing in West Sumatra province today, especially in the rural areas, but not in the urban areas, such as, Padang, Padang Panjang, Bukittinggi, Solok, and Payakumbuh.

Base on Minangkabau philosophy, an egalitarian ethos was the norm where the position of every person or every group was equal to the others. In other words, an individual cannot have a higher position than another. For this reason, excessive reverence to a government official, such as kissing their hand, is a highly reprehensible act in Minangkabau society. Kissing hands in Minangkabau culture only applies to children

29 A.A. Navis, Yang Berjalan Sepanjang Jalan: Kumpulan Karangan Piliban Jakarta: Grasindo, 1999), p. 27.

${ }^{30}$ Ibid. 
as a sign of respect to their parents and pupils to their teachers.

An individual's existence in Minangkabau is valued and respected within the limits of togetherness. The saying "lamak dek awak, katuju dek urang" (good for us, good for others as well) is a reflection that a person was allowed to do anything to benefit themselves, as long as it does not harmed the interests of others. Thus, a principle of life was finding the balance between an individual's life and social life. The egalitarian character of Minangkabau society allows individual the opportunity to compete with each other for their dignity and wealth either as an individual or as a group. ${ }^{31}$

A second factor influencing the character of Minangkabau people is the process of merantau (to leave the homeland, experience life independently and learn from onother culture's way of life). The purpose of merantau is reflected in the proverb "Ka rantau madang dabulu, babuah babungo balun, ka rantau bujang dabulu, di rumah paguno balun" (as a teenager, you are not yet useful at home. You have to go on merantau to have many experiences and become wise).

Due to merantan culture, the Minangkabau customary rules are a accustomed to adaptation with progressive ideas. The tradition of merantau has brought social and cultural changes to Minangkabau people's values. Those who have returned from other areas in the region or even overseas often bring new ideas for the betterment of their society. Therefore, the critique of the Minangkabau tradition often comes from Minangkabau themselves. ${ }^{32}$ The ideas of reform also include the reform relating to views about religion. Once a new idea to change their customary rules arises, conflicts invariably occur. The conflict occurs because of a clash of ideas between Minangkabau people returning from overseas with people who live in their village. However, usually conflict can be resolved through musyawarah jo mufakat (discussion to reach a consensus).

Musyawarah jo mufakat was the hallmark of Minangkabau people in resolving their problems. In the decision making process, Minangkabau people always conducted discussions based on the principle of alue Jo patuik (rationality) by considering conditions, circumstances, time, and

${ }^{31}$ Ibid, pp. 56-60.

${ }^{32}$ Mursal Esten, "Identiti Melayu Minangkabau di dalam Proses perubahan Budaya" in Sastri Yunizar Bakri (ed.), Menelusuri Jejak Melayu Minangkabau (Padang: Yayasan Citra Budaya, 2002), p. 78 
place. In other words, a decision that was made did not apply to all circumstances and times. Musyawarah jo mufakat is clearly a tradition that contains democratic values and has been carried out by Minangkabau people for centuries. ${ }^{33}$ Social changes in Minangkabau were considered normal. Therefore, the Minangkabau customary rules are a subject that can be changed. There was a proverb, sakali aie gadang, sakali tapian baranjak (after the river floods, the edge of the bank changes), expressing an image of Minangkabau's openness to changes that occur in society. ${ }^{34}$

Not all change was positive. A result on the consequence of merantan culture in the beginning of $19^{\text {th }}$ century had disastrous consequences. The conflict between those who have returned from Mecca and those who live in Minangkabau could not be resolved through musyawarah jo mufakat. In 1803, three pilgrims returned to Minangkabau; Haji Miskin, Haji Abdul Rahman and Haji Muhammad Arif. Following their return from Mecca, they insisted that the complete transformation of Minangkabau society into an Islamic community could only be achieved through the use of force. ${ }^{35}$

Haji Miskin's puritan religious movement was supported by Tuanku ${ }^{36}$ Nan Renceh. Bukit Kaman, Tuanku Nan Renceh's village was used as the cradle of their movement, where these two protagonists prepared their plan to impose a more puritan form of Islam on the society. Gradually, Tuanku Nan Renceh was able to build a strong alliance with seven other leading ulama ${ }^{37}$ in Agam. Their ferocity earned members

${ }^{33}$ Mattulada, "Demokrasi dalam Tradisi Masyarakat Indonesia", in M. Amin Rais, Demokrasi dan Proses Politike (Jakarta: LP3ES, 1986), pp. 3-15.

${ }^{34}$ Zainal Arifin, "Kompromi Dasar Kehidupan Orang Minangkabau: Sebuah Pemikiran Awal" in Yerri S Putra (eds.), Minangkabau Dipersimpangan Generasi (Padang: Faculty of literacy, Andalas University, 2007), pp. 165-166.

35 Ulrich E. Kratz and Andriyetti Amir, Surat Keterangan Syekh Jalaluddin (Kuala Lumpur: Dewan Bahasa dan Pustaka, 2002).

36 "Tuanku" was a title given to high-ranking ulama in Minangkabau who were recognized authorities in the Islamic sciences.

37 The term 'ulama is most widely used to refer to the scholarly class of Muslim societies, whose main occupation is the study of the texts that make up the Islamic Tradition (religious sciences such as Qur'an, h.adith, tafsir (Quranic commentary), jurisprudence, and theology), but also the applied sciences such as medicine, biology, astronomy, and mathematics. 
the epithet 'barimau nan salapan ${ }^{38}$ or eight tigers. ${ }^{39}$ Tuanku Nan Renceh declared jihad (holy war) on those who refused to accept the Padri's form of Islam and decreed to people of his own village that an observance strict of Puritanism must be followed.

Historically, Islam had already entered Minangkabau society in the early sixteenth century. ${ }^{40}$ Though, its impact was marginal. A contemporary manuscript written in 1761, stated that most people in the inner highland were pagan or without religion with the exception of notables who converted to Islam. ${ }^{41}$ Furthermore, W. Marsden who visited Minangkabau in 1799 observed that Minangkabau Muslims generally rarely performed Islamic obligations such as prayer and fasting. Attendances at mosques were also poor. ${ }^{42}$

The Padri movement attempted to impose their strict interpretation of Islam throughout Minangkabau society by by force. The outward manifestations of the Padri village were the abandonment of cock fighting, gambling and the use of tobacco, opium, betel and alcohol. White clothes symbolizing purity were also to be worn, with women covering their faces and men sporting beards. ${ }^{43}$

During their conquests and control of Minangkabau, the Padri's inflicted various forms of violence on people from all levels of society including ulama and pious Muslims. In fact, the Padri's even targeted the Syattariyah sufi order, which they suspected of challenging their religious

${ }^{38}$ Harimau nan Salapan refers to Tuanku Nan Renceh, Tuanku Pasaman, Tuanku Rao, Tuanku Tambusai, Tuanku Lintau, Tuanku Mansiangan, Tuanku Pandai Sikek and Tuanku Barumun.

39 Christine Dobbin, Islamic Revivalism in changing peasant economy Central Sumatra, 1787-1847, $2^{\text {nd }}$ edition (London: Curzon Press 1987), p. 134.

40 Taufik Abdullah, "Schools and Politics: The Kaum Muda Movement in West Sumatra 1927-1933”, Monograph Series No 50, Cornell Modern Indonesia Project, Cornell University 1971, pp. 94-102; "Adat and Islam: An examination of conflict in Minangkabau" in Ahmad Ibrahim, Sharon Siddique and Yasmin Hussain (eds.), Readings on Islam in Southeast Asia (Singapore: Institute of Southeast Asia Studies, 1985).

${ }^{41}$ Christine Dobbin, Islamic Revivalism, pp. 12-38.

${ }^{42}$ Mohd Afandi Salleh and Hafiz Zakaria, "From Mekkah to Bukit Kamang: the Moderate versus Radical Reform in West Sumatra 1784-1819”, International Journal of Humanities and Social Science, 1, 14, October 2011, p. 135.

43 Christine Dobbin, Islamic Revivalism, p. 132. 
authority in Minangkabau. ${ }^{44}$ Dobbin describes Padri's behaviour:

To show their contempt for the order, they burnt down Paninjauan ...one of the earliest Syattariyah centres in the highlands, with a large population of religious students...Next they turned their attention to the Empat Angkat area, and a war was waged against Koto Tuo (the main target was their own teacher, Tuanku Nan Tuo at Empat Angkat) and surrounding villages for six years...They looted and robbed the wealth of the people...They killed the ulama and all the orang cerdik (pundits). They captured married women, wedded them to other men, and made their women captives their concubines. Still they called all their actions, actions to perfect religion. ${ }^{45}$

By 1815, the Padri managed to establish their rule throughout Minangkabau and some areas of Tapanuli. ${ }^{46}$ They imposed a strict code of conduct on the Minangkabau society. A penalty system was implemented for the violation of the Padri rules and each village dominated $\mathrm{d}$ by the Padri must appoint a qadi whose jurisdiction laid in religious matters as well as Islamic judiciary. Abd A'la contends that the Padri committed structural, cultural and occasional violence in West Sumatra: ${ }^{47}$

The Padris committed cultural violence by justifying what they did by means of religion, ideology, language and knowledge... They systematically designed structural violence by marginalizing their opponents among individuals and groups of Minangkabau ...This structural violence was then followed by occasional violence in the form of physical attacks, abduction and even assassination.

The Padri movement succeeded to imposing their values to the kelompok adat (indigenous groups) by establishing an agreement known as the Marapalam ${ }^{48}$ charter. $^{49}$ The content of the agreement is "adaik

${ }^{44}$ Mohd Afandi Salleh and Hafiz Zakaria, "From Mekkah to Bukit Kamang", pp. 197-198.

45 Christine Dobbin, Islamic Revivalism, p. 135.

46 Mangaradja Onggang Parlindungan, Tuanku Rao, Terror Agama Islam Mąhab Hambali di Tanah Batak (Yogyakarta: LKiS, 2007), p. 93.

${ }^{47}$ Abdul A'la, "the Genealogy of Muslim Radicalism in Indonesia: A Study of Roots and Characters of the Padri Movement", Journal of Indonesia Islam, 2, 2, 2008, p 238.

${ }_{48}$ Marapalam is the small area at the base of Mount Sago, Lintau, in the Tanah Datar Region

49 Rikardo Simarmata, Pengakuan Hukum terbadap Masyarakat Adat di Indonesia (Jakarta: RIPP-UNDP, 2006), p. 160. 
basandi syarak, syarak basandi kitabullah, syarak mangato, adaik mamakai (Minangkabau customary laws are based on the shari'ab and the shari'ah is based on Quran. Whatever the Quran says, Minangkabau customary laws will follow)..$^{50}$

By establishing the Marapalam Charter, the Padri movement succeed to change the structure of political power in Minangkabau. Before the Marapalam Charter, the position of penghulu as head of their tribe is one among other key positions, namely manti ${ }^{51}$ and dubalang ${ }^{52}$. After the establishment of Marapalam Charter, an additional leadership position was created, namely Imam. All of the leadership position is called 'urang ampek,jinih', (the four types of people), penghulu, imam, manti and bulubalang. ${ }^{53}$ In customary Minangkabau practice, a penghulu role is differentiated from an imam, "kato penghulu kato panyalasai, kato imam kato bakikat" (the penghulu's vocation is to resolve conflict; the imam's vocation is to guide people explaining the fundamental rules which they must live in order to be 'good' Muslims). Prior to the Padri movement, penghulus had regulated various prohibitions and taboos relating to the adat action contrary to Islam. Under rules established by Padri, a penghulu must be a good practicing Muslim, a man, have indigenous linage, good character, knowledgeable, and capable. ${ }^{54}$ These new norms were contrary to indigenous tradition and weakened the penghulu's position in Minangkabau society.

Although the Padri movement was unsuccessful in acquiring support from the majority of Muslims in Minangkabau, they succeed in introducing Islamic Puritanism to society. Therefore, it was not surprising that a 'second wave' of puritan, Kaum Mudo, arose again in Minangkabau in the early twentieth century. This movement was pioneered by Syekh

${ }^{50}$ There is no certainty over the date when the Charter was declared at Mount Marapalam. It would be sometime before the hills of Marapalam were controlled by the Dutch in 1832. For a debate on this issue, see Andi Asoka, Sumpah Satie Bukik Marapalam. Antara Mitos dan Realita (Faculty of Humanity and the Local Government of West Sumatera, 1991). See also Syafnir Abunain. Sumpah Satie di Bukit Marapalam, Perpaduan atara Adat dengan Syarak (Padang: Andalas University, 1991).

${ }^{51}$ Manti is to convey the decisions have been made by penghulu in the meeting of Nagari level.

${ }^{52}$ The task of Hulubalang is to implement the decision made by penghulu

${ }^{53}$ Syafnir Abunain, Sumpah Satie di Bukit Marapalam, p. 115.

54 A.A., Navis, Yang Berjalan Sepanjang Jalan, p. 138. 
Muhammad Djamil Djambek, Syekh Ahmad Khatib, Syekh Taher Jalaluddin, Syekh Ibrahim Musa, Abdul Karim Amrullah, Abdul Ahmad, and Zainuddin Labai Al-Junusi. Although these two respective movements were influenced by the Wahabism purification movement in Mecca, the Kaum Mudo adopted a different typology in their strategy to achieve their vision of an ideal society according to their interpretation on Islamic teaching. While, the Padri movement opted for a top-down strategic model by using armed struggle to achieve their goal, Kaum Mudo decided to use a bottom-up strategic model by becoming a social movement and focusing their movement at the society level. By using a soft approach, 'Kaum Mudo' succeeded to disseminate their ideas to purify Islam peacefully in West Sumatra.

Instead of using armed struggle to achieve their goal, the Kaum Mudo movement disseminated their ideas through sermons, muzakarah (religious discussions), and through publications, like books, whether in Arabic or Malay, articles, magazine, and newspapers, and through brochures. Among others, Al-Munir, published in 1911, and Al-Akbbar, published two years later, in 1913, were the key magazines used to disseminate their religious purification ideas. The Kaum Mudo movement also succeed in establishing schools, such as the Islamic School of Adabiyah in 1909, Madrassah Al-Diniyah in 1915, and Thawalib in 1919. The spread of these new ideas led to the establishment of modernist Muslim organisations, such as, Muhammadiyah, Al-Irsyad and Persis. ${ }^{55}$ This movement succeeded in gaining support from Minangkabau people in the urban areas, such as Padang, Padang Panjang, Payokumbuh, Solok, and Bukittinggi.

\section{Modern State and the Political Islam of Minangkabau People}

By understanding the Islamic purification movement's character in West Sumatra, it is not surprising why efforts of Minangkabau people to implement shari'ah law as a part of Indonesian constitution began in the early days of independence in 1945. Minangkabau people were

55 Azyumardi Azra, "Bali and Southeast Asian Islam: Debunking the Myths", in Kumar Ramakhishna and See Seen Tan (eds.), After Bali: The Threat of Terrorism Southeast Asia" (Singapore: Institute of Defence and Strategic Studies Nanyang Technological University and World Scientific Publishing, 2003), pp. 31-50. 
greatly influenced by 'Kaum Mudo' the Islamic purification movement. ${ }^{56}$ Therefore, the West Sumatra province was the bases of political power for Islamic parties in Indonesia during the first country's democratic election in 1955. Masjumi received $49 \%$ of the vote, while the Tarbiyah Islamiyah Party (Perti) gained 28\% while the Indonesia Communist Party (PKI) gained 7\% and the Party of Syarikat Islam Indonesia (PSII) collected 3\% of the votes. While the Indonesian National Party (PNI) won the elections at the national level, they only received $1 \%$ of their votes from West Sumatera.

Through the Masyumi party, Minangkabau people who were influenced by the Kaum Mudo movement had hoped to establish an Indonesian political and society, based on the 'Islamic teachings'. However, lacking majority representation in the Constitutional Assembly (Majlis Kostituante) and its prolonged and unresolved debates over the state ideological basis, political Islam's goal could not be materialised. ${ }^{57}$ Moreover, Masyumi was banned by President Sukarno in 1960 due to the excessive involvement of their cadres in the Revolutionary Government of Indonesian Republic (Pemerintah Revolusioner Republik Indonesia, PRRI) rebellion. The condition was exacerbated by the strong secularist character of Guided Democracy (1958-1966) by President Sukarno.

The PRRI incident became a turning point in the history of Minangkabau people. During the war between PRRI and the central government, a significant amount of infrastructure was destroyed with large numbers of Minangkabau people killed. Under Guided Democracy's political system, the power structure in West Sumatra was switched from the rule of local leader to military control. Following the defeat of the PRRI, the military had complete authority to appoint local leaders. Although penghulu were still leaders their tribes, in essence, their powers was taken over by the army. As a result, the local leaders only implemented

${ }^{56}$ Islam is a powerful force in Minangkabau culture and politics particularly since the Kaum Muda ulama (Islamic modernist scholars) dominated Minangkabau social and political movements from 1927 to 1933 . Their activities, primarily in the realm of religion and education, had a great impact on Minangkabau society as a whole. For further studies, see Taufik Abdullah, "Schools and Politics: The Kaum Muda Movement in West Sumatra 1927-1933”, Monograph Series No 50, Cornell Modern Indonesia Project, Cornell University 1971.

57 Anies Rasyid Baswedan, "Political Islam in Indonesia", p. 670. 
the rules that were established by the government, following the Guided Democracy system. Moreover, the military which held a central position in the local government was pro-communist. ${ }^{58}$ They were not only anti PRRI, but also anti Masjumi and PSII.

The centralised government under guided democracy had also undermined the 'local democratic values' of the Minangkabau people. Under such situations, the inherent democratic character of local communities could not be realised. There was no scope consultation 'spaces' for discussion to reach consensus as was characteristic of Minangkabau society. The practice of active debating that always occurred among the people gradually declined.

The fall of the Sukarno regime give the rise to optimism that the Minangkabau people could once again involved in local and national's politics. However, this optimism proved still born when the New Order regime implemented a military backed centralised political system. The Minangkabau people may have been 'saved from the tiger's mouth but ended up in the crocodile's.' In 1973, the political party simplified. Four Islamic political parties were forced in to merger and become a single entity, namely, the United Development Party (Partai Persatuan Pembangunan/PPP). Moreover, in the early 1980s, the Suharto regime succeeded to contain Islamism by requiring all Islamic political parties adopt the Pancasila as their asas tunggal or sole organising ideology. Now, all religious parties were required to get rid of their religious platform and opt for secular Pancasila-base ideology. ${ }^{59}$

Under the New Order regime, all the local political elements were precisely regulated in a centralised manner with no regard to the heterogeneity of local political systems which had existed long before the establishment of the modern Indonesia state. In 1979, nagarr ${ }^{60}$ which

${ }^{58}$ G. Moedjanto, Indonesia Abad Ke 20: Dari Perang Kemerdekaan Pertama Sampai PELITA III (Yogyakarta: Kanisius, 1988), p. 23.

59 Anies Rasyid Baswedan, "Political Islam in Indonesia", p. 672.

${ }^{60}$ Nagari is the lowest administrative level in Minangkabau. It is made up of a territory, a political structure and its own legal system. To become a nagari, the community had to fulfil certain requirements: minimum of four tribes already settled in the area; a meeting point where people can gather (balai adat); a mosque (masjid), arable areas; roads and an access to water (tapian tampaik mandi); see Tsuyoshi Kato, Adat Minangkabau dan Merantau, p. 2-3. 
had sovereign status, was autonomous, and had governed its people in a democratic manner was removed and replaced with the desa system (a top-down centralised political system), adopted from Java. ${ }^{61}$ This centralised system destroyed traditional institutions and culture at the local level that had existed for hundreds of years. ${ }^{62}$

The centralised system not only changed the system and form of local government, but also influenced the Minangkabau people's political behaviour. Minangkabau people become more and more politically pragmatic society. It can be seen from the results of the elections under the New Order regime where the majority of Minangkabau people voted for the Golkar. The number of votes Golkar party gained during the New Order regime in West Sumatera almost always exceeded the average of the national share of the votes for the party, dominating the number of seats in the Local House of Representatives (Dewan Perwakilan Rakyat Daerah, DPRD) (See Table 3). ${ }^{63}$

\section{Table 3:}

Seats division in the local parliament (DPRD) as a result of the election under the New Order in West Sumatera (1971-1997)

\begin{tabular}{|l|c|c|c|c|c|c|}
\hline \multirow{2}{*}{ Party/Faction } & \multicolumn{7}{|c|}{ Elections (years) } \\
\cline { 2 - 7 } & $\mathbf{1 9 7 1}$ & $\mathbf{1 9 7 7}$ & $\mathbf{1 9 8 2}$ & $\mathbf{1 9 8 7}$ & $\mathbf{1 9 9 2}$ & $\mathbf{1 9 9 7}$ \\
\hline Golkar & 20 & 21 & 19 & 28 & 30 & 33 \\
\hline PPP & 11 & 11 & 13 & 7 & 5 & 3 \\
\hline PDI & 1 & 0 & 0 & 1 & 1 & 0 \\
\hline ABRI & 8 & 8 & 8 & 9 & 9 & 9 \\
\hline Total & $\mathbf{4 0}$ & $\mathbf{4 0}$ & $\mathbf{4 0}$ & $\mathbf{4 5}$ & $\mathbf{4 5}$ & $\mathbf{4 5}$ \\
\hline
\end{tabular}

Under the New Order regime, public participation in campaigns and the elections seemed very high. This occurred due to mass mobilisations conducted by the Golkar party and the state apparatus that were not neutral. All of the civilian officers campaigned for the Golkar party. The military, police, and bureaucracy were not impartial and influenced

${ }^{61}$ Gusti Asnan, "Penguasa Militer dan Pemerintahan Daerah: Sumatera Barat Akhir 1950-an dan awal 1960-an”, Analisis CSIS, No.4, 2003, p. 529.

${ }^{62}$ Mestika Zed, Sumatera Barat di Panggung Sejarah 1945-1995 (Jakarta: Sinar Harapan, 1996), p. 294.

${ }_{63} \mathrm{Ibid}$. See for results Syamsuddin Haris, Dinamika Politik DPRD Sumatera Barat, Ketika Kekecewaan Rakyat Menggumpal (Jakarta: LIPI, 2001). 
election results. With huge funds at their disposal and support from the bureaucracy and the security forces, the campaigns Golkar party campaign were always well attended.

Political pragmatism was also the order of the day especially with local leaders who ruled and were influential in West Sumatera. This phenomenon is reflected in the widespread act of customary titles being given to national figures who were not of Minangkabau decedent. These local leaders were raised under an authoritarian political culture that influences their political behaviour. These local elites were also likely to be pragmatic, and 'conservative' in the face of progressive ideas that developed in the society. The rigid and hierarchical bureaucratic system had allowed 'feudalism' to thrive in West Sumatera. These local elites revolved around a political culture that was semi feudal, patrimonial and authoritarian. For instance, the Pemuda Pancasila, the biggest youth organisation in West Sumatera under New Order, evolved into an organisation dominated by thugs. This paramilitary organisation functioned as a political pressure group to intimidate the people to support the regime. They were also supported by the security officials. ${ }^{64}$

Under the New Order regime, principles of egalitarianism considered the 'hallmark' of Minangkabau culture could not be implemented. The Minangkabau people tended to obey every single order given by the autocratic regime in Jakarta. Practices of consensus and consultation evident in previous eras were no longer practiced. There were no more debates among the people as seen in previous eras.

Such pragmatic behaviour was also reflected in the existence, function, and role of the Non-Governmental Organisations (NGOs). The character of these organisations was greatly influenced by the autocratic model imposed by the New Order. ${ }^{65}$ Under the regime, NGOs were generally the subordinate of the state representative. As a result, the style of leadership those leading such organisations were not just merely 'feudalistic', but also tended to be elitist. For instance, Lembaga

${ }^{64}$ Andrinof A. Chaniago, "Rintangan-rintangan Demokratisasi di Indonesia", in Maruto M.D. and Anwari M.K. (eds.), Reformasipolitik dan Kekuatan Masyarakat: Kendala dan Peluang Menju Demokrasi (Jakarta: LP3ES, 2002), p. 29

65 Taufik Abdullah, "Pengantar," in Audrey Kahin, Dari Pemberontakan ke Integrasi: Sumatra Barat dan Politik Indonesia 1926-1998 (Jakarta: Yayasan Obor Indonesia, 2005), p. xvii. 
Kerapatan Adat Alam Minangkabau (LKAAM, the Foundation of Minangkabau Customary Laws), established at the beginning of the New Order always supported the Golkar party. Although the the organization had idealistic aims, namely to preserve the local customs, traditions and culture of the Minangkabau people, in practice, the LKAAM tended to be a political instrument of the ruling regime to control the kelompok adat (indigenous groups). A number of social groups also emerged under the New Order regime such as women's, intellectual's, civil servants', youth and journalist's organisations. For instance, the establishment of the women's organisation, Bundo Kanduang, did not merely focus on cultural issues, but also had a political aims, namely to bolster the legitimacy of the regime in power. The leadership group comprised members who were legislators from the Golkar party.

The pragmatic attitude also occurred among the Islamic organisations. Many Islamic scholars and Islamic activists supported the Government Party in elections. For instance Persatuan Tarbiyah Islamiyah (PTI, Unity of Tarbiyah Islamiyah), in the 1955 elections affiliated with the Islamic parties; however, when the New Order regime came to power, they were split into two entities. One faction affiliated with the Golkar party while the other one became the supporter of an Islamic party, Partai Persatuan Pembangunan (PPP, United Development Party). A similar situation also occurred in the Muhammadiyah, many cadres of this organization were the members of the Golkar party. Moreover, a large number of traditionalist Muslim charismatic leaders, whose words have traditionally been followed by Muslim villagers in West Sumatra, also support for Golkar party.

\section{E. Post Suharto West Sumatra}

Although the Suharto's authoritarian regime was replaced by a democratic system, the pragmatic attitude of Minangkabau people toward politics had not changed. This was evident from the results of the 1999 election. The 1999 election results clearly illustrated the pragmatic character of Minangkabau people toward electoral politics. Golkar party, the dominant party under Suharto regime, considered the party that destroyed traditional institutions and Minangkabau culture, ironically, won the legislative election in West Sumatra (see Table 4). 


\section{Table 4:}

the election result from the 1999 election in the province of West Sumatera (DPRD1)

\begin{tabular}{|l|l|l|}
\hline Party/Factions & Votes & Seats \\
\hline Golkar & 464.729 & 12 \\
\hline PAN & 423.315 & 11 \\
\hline PPP & 402.359 & 10 \\
\hline PDI Perjuangan & 213.749 & 5 \\
\hline PBB & 115.928 & 3 \\
\hline Partai Keadilan & 58.375 & 2 \\
\hline PII Masyumi & 34.556 & 1 \\
\hline PKP & 22.829 & 1 \\
\hline PUI & 21.184 & 1 \\
\hline KAMI & 20.868 & 1 \\
\hline PKB & 17.553 & 1 \\
\hline Parti Persatuan & 16.925 & 1 \\
\hline TNI/Polri & - & 6 \\
\hline
\end{tabular}

Sources: 1999's General Election in numbers, Direktorat Sosial Politik (Ditsospol) of West Sumatera province

Instead of implementing the reform agenda, namely, improvements of bureaucracy and public services, the members of the West Sumatera DPRD 1999-2004 were involved in a variety corruption scandal. Padang District Court found 43 members of the West Sumatra provincial legislative council guilty of corruption involving the 2002 provincial budget. ${ }^{66}$ Rampant corruption cases in West Sumatera damaged the image of the regional parliament a pattern evident across Indonesia. The cases not only involved members of the legislature at the provincial level, but also some members of parliament and kotamadya at district levels, namely, Lima Puluh Kota, Padang, Padang Pariaman, Payakumbuh, Agam and Tanah Datar districts.

Ironically, even though a string of corruption cases implicating member of the West Sumatera DPRD from 1999-2004 had been revealed, it did not influence the voting behaviour of the local population in the

66 "Mantan Ketua DPRD Sumbar Kembali diperiksa kasus korupsi APBD Rp 6,4 milliar," Tempo Interaktif, November, 3, 2004. 
2004 general election. The Golkar Party remained the winner gaining 16 seats in the Legislative Assembly of West Sumatera province. Ironically, the Golkar party gained an extra four seats compared to the 1999 elections. (see table 5)

\section{Tabel 5:}

The 2004 West Sumatera election result for DPRD I.

\begin{tabular}{|l|c|}
\hline Political Party & Seats \\
\hline PBB & 5 \\
\hline PPP & 7 \\
\hline Democrat Party & 3 \\
\hline PAN & 10 \\
\hline PKS & 7 \\
\hline PBR & 3 \\
\hline PDI P & 4 \\
\hline Golkar Party & 16 \\
\hline
\end{tabular}

Sources: Regional General Election Commission (Election Commission) of West Sumatera province in 2004.

Many observers concluded that the beginning of the reformation era in Indonesia was the era of the return of 'old' politicians even though some of them came wrapped in 'new clothes', in both political and economic sense. ${ }^{67}$ The West Sumatra province was not an exceptional to this trend. 'Old' politicians who had accumulated vast amounts of money during the New Order regime had a better chance of staying in power. Moreover, the ideas of democracy, human rights and freedom of speech were used only to protect their interests. ${ }^{68}$ The result of the 2004 elections illustrated that there were no fundamental changes in the political structure of the West Sumatera province. The power to mobilize funds was the most decisive factor in the victory of the Golkar party in the 2004 legislative elections aided by the 'pragmatism' of the people in West Sumatera.

Based on the experienced learned during 1999 election, West Sumatera commonly realised that the political system after the fall of

${ }^{67}$ Vedi R. Hadiz, "Menimbang Gagasan Transisi di Indonesia" in AE Priyono, Stanley Adi Prasetyo, Olle Tornquist (eds..), Gerakan Demokrasi di Indonesia Pasca-Soeharto (Jakarta: Demos, 2003), pp. 58-59.

${ }_{68}$ Andrinof A. Chaniago, "Rintangan-rintangan Demokratisasi”, p. 29 
Indonesia's New Order regime could not assure that their aspirations would be fulfilled. Based on interviews in Tanah Datar regions, the establishment of political parties and elections were viewed by electorate as unproven from a material stand point and provide no guarantees that their political interests would be realised. For many of them, the political representative is just a figment of their inspiration. Datuak Panghulu Basa, head of the Jambak tribe in Malalo, Tanah Datar stated:

"Based on our experience from the 1999 to 2009 elections, once the election was over, the people returned to their work and politicians to their political intrigues. We neither met nor recognised each other again. How can we believe that the elected legislative will represent the real will of the people? I don't think so". ${ }^{69}$

For this reason, the local community quickly established a mechanism to force prospective legislative candidates to meet their demands before the elections were held. For instance, before the 2004 election, the local community formed a committee to welcome prospective legislative members in some nagaris in the Tanah Datar region. They organised collective strategies to confront prospective legislative members in their social institutions. With the approval of all citizens, the committee offered a service to facilitate a meeting between local people and the prospective legislative members.

The committee then set a place and time for a prospective legislator to campaign. In the meeting, the committee set up a 'ploy' that tried to convince the prospective legislative member that the people agreed to give their support. At the end of the meeting, residents asked for some funds or goods to be disbursed by prospective legislative members. Depending on the speed of the disbursement of funds or material possessions to citizens, the sooner the community agreed to provide the political support required to secure the election for a prospective legislator. Therefore, with the power to mobilise capital, the Golkar party secured their winning position in the 2004 election in West Sumatera.

The deal between the people and the prospective legislative members was often artificial and just a trick by the local community who now felt totally protected when exercising their freedom to vote. No one

${ }^{69}$ Interview with Datuk Panghulu Basa, Head of Jambak Tribe in Malalo, Tanah Datar, was conducted on September 2011. 
was able to exercise their right to vote independently. In many cases, the 'ploy' set by the people was not just for a prospective legislative member only, but was applied to every member who came campaigning in their area. For prospective legislative members, the pragmatic attitudes of voter behaviour were a difficult political risk that had to be factored into their political equation. Prospective legislative members were aware that the amount of funds and material goods they provided to the people in many cases were not equal to the number of votes they gained. The politicians were also aware that the commitment of people to give their support could not be trusted. People could simply break their commitment at the last minute just as a politician could break their promises made during the campaign.

In the 2004 election, this pattern was a regular occurrence in all of Indonesia's provinces. Public demand for the advance provision of funds in advance was a political strategy to meet their needs. The acceptance of money politics should not be seen as a negative public attitude or opportunism. It was a primary strategy in providing the voter with some semblance of control towards an elected legislative member. Seen in this light, money politics was fully rational aspect of the electoral system which while unable to produce good quality political representation, nevertheless, and was able to extract state resources for the benefit of its constituents.

In the 2009 election, the contours of political power in West Sumatera were altered. The Democrat Party that had previously only won three seats, now received up to 14 seats. Golkar party having obtained 16 seats in the previous election now dropped to nine seats (see table 6 below). This change did not mean that there was a shift in political behaviour at the societal level. It was actually an indication that the voter behaviour remained the same as in previous elections. The success of the Democrat party in West Sumatera also reflected the pragmatic political behaviour of Minangkabau society willing to exercise flexibility primarily because the Democrat was the government party.

Considering the pragmatism of Minangkabau people and election outcomes after the Soeharto era where secular parties always triumphed in legislative elections, we should not conclude that political Islam is not a threat to the democratic process in the province. By contrast to the 


\section{Table 6:}

Votes and Seats in the parliament at the Provincial level of West Sumatera province based on the 2009 election

\begin{tabular}{|l|c|c|}
\hline Political party & Votes & Seats \\
\hline People Conscience Party (Hanura) & 102,324 & 5 \\
\hline $\begin{array}{l}\text { Great Movement Indonesia Party } \\
\text { (Gerindra) }\end{array}$ & 79,649 & 4 \\
\hline Prosperous Justice Party (PKS) & 186,866 & 5 \\
\hline National Mandate Party (PAN) & 221,399 & 6 \\
\hline Golkar Party & 316,374 & 9 \\
\hline United Development Party (PPP) & 139,760 & 4 \\
\hline Crescent Star Party (PBB) & 80,398 & 3 \\
\hline $\begin{array}{l}\text { Indonesian Democratic Party-Struggle } \\
\text { (PDIP) }\end{array}$ & 71,264 & 3 \\
\hline Reform Star Party (PBR) & 58,447 & 2 \\
\hline Democrat Party & 471,124 & 14 \\
\hline
\end{tabular}

Sources: Regional General Election Commission (Election Commission) of West Sumatera province in 2009.

1955 election, post reformasi condition in West Sumatra province seemed to suggest that Islamic parties had no significant political base. However, this does not mean that political Islam in West Sumatra is in decline since the facts indicate otherwise. Although the support for Islamic political parties has declined, a large number of local regulations (Perda) based on shariah law have been implemented at the provincial and district level.

\section{F. Political Islam in West Sumatra: Wayang vs Dalang}

The implementation of shari'ablaws promoted by secular parties in West Sumatera was not surprising since many Islamic organisations opted to spread their members in various political parties. Muhammadiyah, the biggest Islamic organisation in West Sumatra is the most active organisation encouraging their cadres to join in the political parties regardless of their ideological backgrounds. The branches of all of the nationalist and secular political parties in West Sumatra were penetrated by the Muhammadiyah. Some Islamic traditionalist streams followed suit. Rahmat Tuanku Sulaiman, one of the prominent figures among ulama 
of Syattariyah, sufi order, in Padang Pariaman stated:

"We are not supposed to only join Islamic political parties; we have to spread our people to the secular parties as well. By joining Islamic parties, we can't do very much. What we need to do are to islamise the secular parties. That is the reason why I joined the Golkar party" 70

As well as the establishment of shariah laws at the provincial and regional levels, the public sphere in West Sumatra is controlled by Islamists. According to a report by the Setara Institute, in West Sumatera province, the rate of politicisation of religion is particularly high. This province recorded the second highest number of incidents of violations to freedom of religion in Indonesia. ${ }^{71}$ For instance, at the beginning of 2012, a civil servant, Alexander Aan, posted a message on the Facebook page of 'Atheist Minang', which he created. The post so enraged residents in Aan's hometown of Pulau Punjung in West Sumatra that an angry mob of dozens stormed his office and beat him up. To add insult to injury, police then arrested him and wanted to press blasphemy charges that could see him locked up for five years. ${ }^{72}$

Incidents of violations to freedom of religion and belief in West Sumatra, such as, Aan case and dissolution of Ahmadiyah group in Padang, highlight that Minangkabau people who are well-known as a dynamic, open-minded and egalitarian in their attitude have been replaced by a conservative religious attitude. However, the changes in social behaviour of Minangkabau people; growing religiosity, piety and even more conservative attitude, is occurring along with the decline of support for the Islamic political parties. To understand this paradox, we have to disentangle the role of Islamic political parties and political Islam represented by Islamic movements at the political and societal level.

Based on Indonesian history, from the colonial to the reformasi era, social and political changes were always pioneered by social movements instead of political parties. The behavioural changes evident in Indonesian Muslims leading to hardline conservatism were influenced by the Islamic

${ }^{70}$ Interview with Rahmat Tuanku Sulaiman, committee member of Golkar Party in the region of Padang Pariman, was conducted on May 2012.

${ }^{71}$ Setara Institute, Report of Freedom of Religion/Believe in Indonesia 2008, Siding and acting intolerantly (Jakarta: Setara Institute, 2008).

72 "Activists Call for Acquittal of Embattled Atheist Alexander", Jakarta Globe, 13 June 2012. 
movements. In short, the social movement is the 'dalang' ${ }^{73}$ invisible man who sits behind the screen and 'narrates' the story of Indonesian politics and social change; while, political parties is merely 'wayang' presented to the public.

By understanding the logic of 'wayang', it should be recognised that support for the Golkar party under the Suharto regime cannot be interpreted to mean that Muslims in West Sumatra have changed their political orientations, from religious to secular. In the 'screen' of Indonesian political 'wayang' performance this might be true; however, in the case of rural areas in West Sumatra, it was the role of the ulama, the charismatic Muslim leader, functioning as the 'dalang' that influences the electoral behaviour of the people. When an ulama was committed to support certain party, people would follow. For example, once Syekh Ali Imran Hasan, Head of Pondok Pesantren Nurul Yaqin, a prominent Syattariyah Islamic Boarding School in Padang Pariman district, was committed to support the Golkar party in 1997's election, Syattariyah followers from various part of West Sumatra followed suit. This trend has also occurred among Naqsabandiyah, sufi order followers. Once Buya Taharuddin, prominent Naqsabandiyah sufi order in Padang Laweh, Tanah Datar committed his support for Golkar in the 1997's election, Naqsabandiyah followers adhered to his political decision.

Under the Suharto regime, the presence of ulama had widespread influence throughout the villages in West Sumatra, and was a contributing factor influencing Muslim electoral behaviour. Therefore, it should be recognised that an increase in the number of devout Muslims who did support Golkar in the rural areas could be attributed to the role of the ulama and their decision. Despite being less significant in shaping Muslim electoral behaviour under Suharto regime, the ulama have generally played an important role in politics and society.

We have to bear in mind that the relationship between the ulama and society has long been institutionalised through patron-client norms in West Sumatra. Therefore, the ulama's power is strong enough to influence the people's electoral behaviour. Under the Suharto regime, the ulama and the government party have power in relation to society. They use

${ }^{73}$ Dalang is the genius behind the entire of wayang performance. He sits behind the screen and narrates the story. 
powers to bargain and gain funds for their movement. Unsurprisingly, the Golkar party always won elections.

The role of the ulama in rural areas in West Sumatra has not altered despite the change of political system. Although secular parties have dominated elections in the post Suharto era, it would be a mistake to assume that the influence of ulama in West Sumatra was weakening, particularly their ability to influence voter behaviour. In an interview in Tanah Datar, one of respondents stated:

"I don't really care about the political party's ideology. A lot of elected parliament member from Islamic parties are bad people as well. They were involved in the corruption. I am satisfied if my choice of a party is compatible with what is recommended by Buya Anwar"' ${ }^{74}$

Throughout the post-Suharto era, the ulama's perspectives toward politics had again never altered. Ulamas believe that politics is one of the strategies, among many others, to establish a religious society. Therefore, the ulamas are not necessarily involved in formal politics. For the ulamas at the political level, Islam is a source of political ideas. Critically, they focus primarily in society. Ulamas concentrate on creating a favourable situation for the benefit of people, rather than imposing 'Islamic politics' in a political arena. For instance, Muhammad Rais Tuanku Labai Nan Basa, an ustadz (teacher) in Pesantren Nurul Yaqin, in the Padang Pariaman region stated that:

"The implementation of shariah laws is a political commodity. It does not consider the substance of the shariab itself. The practice of shari'ah should be based on sincerity. A Muslim cannot conduct worship just because the rules in accordance with Islamic law were created by the local government. There is no value for worship because they are not sincere." 75

Nevertheless, Syattariyah, as a social group, succeeded in assigning their members to the local parliament, for example, the deputy of West Sumatra local parliament (2009-2014), Leonardy Harmainy, is a Syattariyah follower. According to Buya Ismet Ismail, Chairman of Syattariyah headquarters in West Sumatra, Riau, Jambi and Bengkulu

${ }^{74}$ The interview was conducted in Batusangkar, West Sumatra in July 2011. The Buya Anwar is prominent Shattariyah ulama in Tanah Datar.

75 The interview was conducted in Pondok Pesantren Nurul Yaqin, RinganRingan Pakandangan, West Sumatra in July 2011. 
province:

"Some of Syattariyah members succeeded in becoming parliament members from various political parties in West Sumatra. They were nominated by PPP, PKB, Golkar, Hanura, PKPB and some other parties"76

The traditional Islamic groups, such as Syatariyah and Naqsabandiyah ${ }^{77}$ have spread their Islamic ideal vision over the society, emphasising the institutionalisation of Islam into people's daily lives or in other words, by using the bottom-up strategic model. This trend is very different compared to the Islamist groups in urban areas, such as, Padang, Padang Panjang, Solok, Bukittinggi, and Payokumbuh. They profess what scholars now understand to be Islamism, namely, "Islam should guide social, political and personal life".

The urban areas in West Sumatra remain the epicentre of a burgeoning public sphere in which informed members of the public debate highly contested Islamic discourses regarding legitimate government, social justice, gender relations and public space. Nevertheless, based on our surveys in Padang city, political Islam is a palpable force manifested everywhere in the city, government, daily consumption, cultural and media productions, civil society groups, social movements and educational institutions.

The situation in West Sumatra is very similar to other Islamic cities in the world. Political Islam operates at multiple levels. It simultaneously envisions itself as a force for the revival of global Islamic unity, a movement to reform the territorially defined national state and creator of moral economy in urban neighbourhoods. ${ }^{78}$ The movement is concentrated among educated youth, such as University students and includes civil servants. They succeed in building networks, not only at the national, but also the international level.

The idea of the establishment of an Islamic state (dawla al-Islämiyyah)

76 The Interview was conducted in Surau Koto Tuo, Agam region, in July 2011.

77 Syatariyah and Naqsabandiyah are two major Sufi streams evolved in West Sumatra.

${ }^{78}$ Paul M. Lubeck and Bryana Britts, "Muslim Civil Society in Urban Public Spaces: Globalization, Discursive Shift, and Social Movements", in J. Eade and C. Mele (eds.), Urban Studies: Contemporary and Future Perspectives (California: Center for Global, International and Regional Studies, University of California, Santa Cruz, Blackwells, 2001). 
is one of the most crucial agendas for these groups. However, along with the regional autonomy laws implemented in Indonesia, their efforts are much more focused on the provincial and regional levels. Such attempts to establish an Islamic society in West Sumatra are carried out through legal process, more precisely, through parliament. Having support from parliament members, these Islamic movements are able to achieve their agendas unhindered and effectively. Most of the parliament members in West Sumatra province support these ideas regardless of the political background of their parties.

In achieving their agendas to establish an ideal Islamic ideal society, Islamist groups created a diverse network of civil society groups providing goods and services, such as, charity, free education, and free treatment. Therefore, they get tremendous support from the society. Moreover, due to endemic corruption, severe economic dislocation and moral degradation in the urban areas in West Sumatra, Islamism have emerged in variety of platform as the most powerful anti-systemic social force opposing corruption, economic disparity and all of the social problems.

\section{G. Conclusion}

In democratic countries, people's advocacy of their religious ideas can be realised through politics, since the democratic system allows political parties to function as a means by which people can articulate their interests, including religious interests. For that reason, some Islamic political parties have been established. Through Islamic parties, Muslims can articulate their religious ideas to regulate their lives. Thus, Islamic political parties, ideally, constitute a means of bridging religious ideals and the reality experienced by Muslims. However, the role of Islamic political parties of bridging religious ideas and politics does not work properly. For instance, instead of bridging Muslims interest, Islamic parties also involve high-profile corruption cases and scandals; for example, the involvement of PKS elites in corruption cases.

Having learned from the experience, people in West Sumatra have lost their 'faith' in the political parties and have returned to their roots into a "pragmatic society" when articulating their political preferences. They no longer see voting for Islamic political parties as a 'requirement' to fulfil the Islamic teachings. However, regarding the issues of religion 
in their personal and social life is very important for them. Therefore, the Islamic movements, like Hizbut Tahrir Indonesia and KPSI are developing effectively at the society level and having greater influence of Islamic political parties. They believe that the shari'ab law has to be implemented by using bottom-up strategic model focusing on the social level. By using a bottom-up strategy, Islamist groups in West Sumatra succeed to control the public discourse involving virtually all social classes, genders and status groups. Therefore, slowly but surely, the public sphere and government in West Sumatra province will be controlled by Islamists. 


\section{BIBLIOGRAPHY}

A'la, Abdul, "the Genealogy of Muslim Radicalism in Indonesia: A study of Roots and Characters of the Padri Movement", Journal of Indonesian Islam, 2, 2, 2008.

Abdullah, Taufik, "Schools and Politics: The Kaum Muda Movement in West Sumatra 1927-1933", Monograph Series No 50, Cornell Modern Indonesia Project, Cornell University, 1971.

----, "Adat and Islam: An examination of conflict in Minangkabau" in Ahmad Ibrahim, Sharon Siddique and Yasmin Hussain (eds.), Readings on Islam in Southeast Asia, Singapore: Institute of Southeast Asia Studies, 1985.

----, "Pengantar" in Audrey Kahin, Dari Pemberontakan ke Integrasi: Sumatra Barat dan Politik Indonesia 1926-1998, Jakarta: Yayasan Obor Indonesia, 2005.

Abunain, Syafnir, Umpah Satie di Bukit Marapalam: Perpaduan atara Adat dengan Syarak, Padang: Andalas University, 1991.

"Activists Call for Acquittal of Embattled Atheist Alexander", Jakarta Globe, June, 13, 2012.

Andrew, Steele, "the Decline of Political Islam in Indonesia 2006, Asia Time, March 28, 2006 [http:/ /www.atimes.com/atimes/Southeast_ Asia/HC28Ae03.html].

“Anggota DPRD Batam Usulkan Pajak 10\% dari PSK", Batam Pos, 15 February 2010.

Arifin, Zainal, "Kompromi Dasar Kehidupan Orang Minangkabau: Sebuah Pemikiran Awal" in Yerri S Putra (ed.), Minangkabau Dipersimpangan Generasi, Padang: Faculty of Literacy, Andalas University, 2007.

Asnan, Gusti, "Penguasa Militer dan Pemerintahan Daerah: Sumatera Barat Akhir 1950-an dan awal 1960-an”, Analisis CSIS, No.4, 2003.

Asoka, Andi, Sumpah Satie Bukik Marapalam. Antara Mitos dan Realita, Padang: Faculty of Humanity, 1991.

Azra, Azyumardi, "Bali and Southeast Asian Islam: Debunking the Myths", in Kumar Ramakhishna and See Seen Tan (eds.), After Bali: 
The Threat of Terrorism Southeast Asia, Singapore: Institute of Defence and Strategic Studies Nanyang Technological University and World Scientific Publishing, 2003.

Barton, Greg, "the Prospects for Islam”, in G. Lloyd and S. Smith (eds.), Indonesia Today: Challenges of History, Singapore: Institute of Southeast Asian Studies, 2001.

Baswedan, Anies Rasyid, "Political Islam in Indonesia: Present and Future Trajectory", Asian Survey, 44, 5, 2004.

Bonner, Robert Johnson, Aspects of Athenian Democracy, California: University of California Press, 1933.

Chaniago, Andrinof A, "Rintangan-rintangan Demokratisasi di Indonesia" in Maruto MD and Anwari MK (eds.), "Reformasi politik dan Kekuatan Masyarakat: Kendala dan Peluang Menju Demokrasi”, Jakarta: LP3ES, 2002.

Chatra, Emeraldy, Adat Selingkar Desa, Padang: Faculty of social and political science and centre of development and social change studies, University of Andalas, 1999.

Daftar Inventarisasi Rancangan dan Produk. Hukum Daerah Kabupaten/Kota Se-Sumatera Barat 2001-2008, Law and Human Right Bureau of West Sumatera Province.

Dobbin, Christine, Islamic Revivalism in Changing Peasant Economy Central Sumatra, 1787-1847 (2 nd $^{\text {ed. }), ~ L o n d o n: ~ C u r z o n ~ P r e s s, ~} 1987$.

Esten, Mursal, "Identiti Melayu Minangkabau di dalam Proses Perubahan Budaya", in Sastri Yunizar Bakri (ed.), Menelusuri Jejak Melayu Minangkabau, Padang: Yayasan Citra Budaya, 2002.

Fealy, Greg, Local Power and Politics in Indonesia: Decentralisation \& Democratisation, Singapore: Institute of Southeast Asian Studies, 2003. ----, “Indonesia's Islamic Parties in Decline” Inside Story, 2009, http:/ / inside.org.au/indonesia $\%$ E2\%80\%99s-islamic-parties-in-decline/

Fuller, Graham E., The Future of Political Islam, New York: Palgrave Macmillan, 2003.

General Election in numbers, Direktorat Sosial Politik (Ditsospol) of West Sumatera province.

Hadiz, Vedi R, "Menimbang Gagasan Transisi di Indonesia", in A.E. 
Priyono, Stanley Adi Prasetyo, Olle Tornquist (eds.), Gerakan Demokrasi di Indonesia Pasca-Soeharto, Jakarta: Demos, 2003.

Hamayotsu, Kikue "The End of Political Islam? A Comparative Analysis of Religious Parties in the Muslim Democracy Indonesia", Journal of Current Southeast Asia Affairs, 30, 3, 2011.

Haris, Syamsuddin, Dinamika Politik DPRD Sumatera Barat, Ketika Kekecewaan Rakyat Menggumpal, Jakarta: LIPI, 2001.

James, William, Pragmatism: A New Name for Some Old Ways of Thinking, New York: New York Library of America, 1986 (1907).

Kato, Tsuyoshi, Adat Minangkabau dan Merantau dalam Presfektif Sejarah, Jakarta: Balai Pustaka, 2005.

Kahin, Audrey, Dari Pemberontakan ke Integrasi: Sumatera Barat dan Politik Indonesia 1926-1998, Jakarta: Yayasan Obor Indonesia, 2005.

King, Dwight, Half-hearted Reform: Electoral Institutions and the Struggle for Democracy in Indonesia, Westport, Conn: Praeger, 2003.

Kratz, Ulrich E and Andriyetti Amir (eds.), Surat Keterangan Syekh Jalaluddin trans. by Faqih Saghir, Kuala Lumpur: Dewan Bahasa dan Pustaka, 2002.

Liddle, R., William and Saiful Mujani, "Leadership, Party, and Religion: Explaining Voting Behaviour in Indonesia," Comparative Politics Studies, 40, 7, 2009.

Lubeck, Paul M. and Bryana Britts, "Muslim Civil Society in Urban Public Spaces: Globalization, Discursive Shift, and Social Movements", in J. Eade and C. Mele (eds.), Urban Studies: Contemporary and Future Perspectives, Santa Cruz: Center for Global, International and Regional Studies, University of California, Blackwells, 2001.

"Mantan Ketua DPRD Sumbar Kembali diperiksa kasus korupsi APBD Rp 6,4 milliar", Tempo Interaktif, 3 November 2004.

Mattulada, "Demokrasi dalam Tradisi Masyarakat Indonesia", in M. Amin Rais, Demokrasi dan Proses Politik, Jakarta: LP3ES, 1986.

Moedjanto, G., Indonesia Abad Ke 20: Dari Perang Kemerdekaan Pertama Sampai PELITA III, Yogyakarta: Kanisius, 1988.

Navis, AA, Yang Berjalan Sepanjang Jalan: Kumpulan Karangan Piliban, Jakarta: Grasindo, 1999. 
Platzdasch, Bernhard, Down but Not Out: Islamic Political Parties did not do well, but Islamic Politics going mainstream, in Inside Indonesia, 97, (2009) [http://www.insideindonesia.org/edition-97jul-sep-2009/down-but-not-out-05071210].

Parlindungan, Mangaradja Onggang, Tuanku Rao, Terror Agama Islam Mąhab Hambali di Tanah Batak, Yogyakarta: LKIS, 2007.

PPIM, The 2001-2012 PPIM Survey, Jakarta: PPIM-UIN Syarief Hidayatullah.

Salleh, Mohd Afandi and Hafiz Zakaria, "From Mekkah to Bukit Kamang: the Moderate versus Radical Reform in West Sumatra 1784-1819”, International Journal of Humanities and Social Science, 1, 14, October 2011.

Sanday, Peggy Reeves, Women at the Center: Life in a Modern Matriarchy, Boston: Cornell University Press, 2002.

Seleny, Anna, "Tradition, Modernity and Democracy: the many promises of Islam”, Prospective on politics, Vol. 4, No. 3, September, 2006.

Setara Institute, Report of Freedom of Religion/ Believe in Indonesia 2008, "Siding and acting intolerantly," Jakarta: Setara Institute, 2008.

Simarmata, Rikardo, Pengakuan Hukum terhadap Masyarakat Adat di Indonesia, Jakarta: RIPP-UNDP, 2006.

“Syariah Bylaws: 'Time Bomb”, Jakarta Post, April, 20, 2012.

Tanuwijaya, Sunny, "Political Islam and Islamic parties in Indonesia: Critical Assessing the Evidence of Islam's Political Decline", Contemporary Southeast Asia, 32, 1, 2010.

Ufen, Andreas, "From Aliran to dealignment: Political Parties in postSoeharto Indonesia", Southeast Asia Research, 16, 1, 2008.

Zed, Mestika, Sumatera Barat di Panggung Sejarah 1945-1965, Jakarta: Sinar Harapan, 1996. 